\title{
Antidiabetic Action of Alfalfa (Medicago sativa) Leaves Powder on Type II Diabetic Patients
}

\author{
Burhan A. Salih*, Kokaz O. Azeez \\ Department of Medical Laboratory Technology, Hawler Health Technical College, Erbil Polytechnic University, Erbil, Kurdistan Region - F.R. Iraq
}

\section{*Corresponding author: \\ Burhan A. Salih, \\ Department of Medical \\ Laboratory Technology, \\ Hawler Health Technical \\ College, Erbil Polytechnic \\ University, Erbil, Kurdistan \\ Region - F.R. Iraq. \\ E-mail: burhan.salih@epu. \\ edu.iq}

Received: 05 November 2018

Accepted: 09 December 2019

Published: 13 June 2019

\section{DOI}

10.25156/ptj.v9n1y2019.

pp23-25

\section{A B S T R A C T}

Type II diabetes is a common metabolic disorder that is specified by hyperglycemia resulting from defects in insulin action. Alfalfa (Medicago sativa) is a medicinal plant (leaves, flower, and seeds) used traditionally as antidiabetic. This study is designed to investigate the short-term antidiabetic action of alfalfa leaves powder in patients with Type II diabetes mellitus. 12 volunteers suffering from type II diabetes were undertaken besides 12 healthy individuals. The subjects were divided into four groups including healthy control, diabetic control, which received an only meal, and the third and fourth groups were healthy and diabetic subjects which received alfalfa leaves powder within the meal. A standard test meal was supplemented with $8 \mathrm{~g}$ of alfalfa. The results showed that alfalfa leaves significantly $(P=0.03)$ reduces blood sugar $2 \mathrm{~h}$ after meal from $344.4 \mathrm{mg} / \mathrm{dl}$ to $300.75 \mathrm{mg} / \mathrm{dl}$ in the diabetic subject, in addition to the elevation of serum insulin levels $(P=0.02)$ at $30 \mathrm{~min}$ and elevation further increased $(P=0.06)$ at $120 \mathrm{~min}$. This finding suggested that alfalfa leaves could be applied as a therapy against Type II diabetes.

Keywords: Alfalfa; Insulin; Type II diabetes.

\section{INTRODUCTION}

Diabetes mellitus is one of the leading public health problems of the modern era (Aydin and Önder 2016) it is a chronic endocrine disorder affecting the body's metabolism and resulting in structural changes affecting the organs of the vascular system (Nathan et al., 2014). Diabetes and its complications bring about the substantial economic loss to people with diabetes and their families and health systems and national economies through direct medical costs and loss of work and wages. Keeping a healthy diet rich in vegetables and fruits as well as regular physical activities are recommended to prevent type II diabetes mellitus for a large population. In addition, identification of new approaches such as the use of specific food components may provide potential prevention and management of Type II diabetes. Alfalfa or green gold is one of the medicinal plants that are used in traditional medicine due to being high in protein, calcium, and vitamins and also its low percentage of cellulose (Amraie et al., 2015). Leaves of alfalfa have been used traditionally in South Africa for treating diabetes in the form of tea (Gray and Flatt, 1997). Administration of alfalfa leaves in the diet $(62.5 \mathrm{~g} / \mathrm{kg})$ and drinking water $(2.5 \mathrm{~g} / \mathrm{L})$ reduced the hyperglycemia of streptozotocin-induced diabetic mice. An aqueous extract of alfalfa $(1 \mathrm{mg} / \mathrm{ml})$ stimulates 2-deoxyglucose transport and glucose oxidation (Gray and Flatt, 1998).

The aim of the present study is to study the effect of alfalfa leaves powder on blood glucose level and serum insulin level in healthy as well as type II diabetic patients.

\section{MATERIALS AND METHODS}

The experiment was a short-term, paired; cross-over study in which each subject received the single treatment. A standard test meal was served with $8.0 \mathrm{~g}$ of alfalfa leaves powder administered orally (Gregersen et al., 2004).

The ingested dose was empirically set to $8.0 \mathrm{gm}$. The test meal consisted of wheat toast $(85 \mathrm{~g})$, total fat $0.5 \mathrm{~g}$, sodium $240.0 \mathrm{mg}$, total carbohydrate $(18.0 \mathrm{~g})$, sugars $(1.0 \mathrm{~g})$, protein $(5.0 \mathrm{~g})$, dietary fiber $(5.0 \mathrm{~g})$, cheese $(30 \mathrm{~g})$, orange juice $(2 \mathrm{dL})$, and 2 cups of tea. The total energy content of the test meal was $3000 \mathrm{~kJ}$.

Twenty four individuals 30-60 years of age subjects were used for this study, weighed between 70 and $140 \mathrm{~kg}$ and length between 160 and $188 \mathrm{~cm}$, they were randomly divided into four groups each six individual that received with single dose of alfalfa powder: Group I: Control 
group who did not received treatment. Group II: Diabetic patients served as diabetic controls who did not received treatment. Group III: Healthy subject received alfalfa treatment, and Group IV: Diabetic patients received alfalfa treatment.

Diabetes is confirmed with $\mathrm{HbA}_{1} \mathrm{C} \geq 48 \mathrm{mmol} / \mathrm{mol}(6.5 \%)$, the subject was fasting for $>12 \mathrm{~h}$, blood samples were collected from subjects per replicate before and 30,120, and 240 min after a meal.

\section{Fasting Glycemia}

At the end of the experimental period, 12-h fasted subjects were tested for the estimation of blood glucose levels, which was measured by spectrophotometer (EMCLAB Germany) at $500 \mathrm{~nm}$.

\section{Serum Insulin Estimation}

Serum insulin levels were quantified using an insulin Enzyme-Linked Immuno-Sorbent Assay kit from (Monobind Inc.). This method is based on the direct sandwich technique, in which two monoclonal antibodies are directed against separate antigenic determinants on the insulin molecule.

\section{Statistical Analysis}

All the data have been entered and processed using GraphPad Prism (Version 6). The comparison was conducted in between "healthy and their control group" or in between "diabetic and their control group." A two independent group's student t-test was used to compare the significance of changes in parameters at each time. $P \leq 0.05$ was considered statistically/significant.

\section{RESULTS AND DISCUSSION}

The current results showed the effect of alfalfa leaves powder on plasma glucose in control and experimental groups of subjects [Table 1 and Figure 1]. The mean level of blood sugar

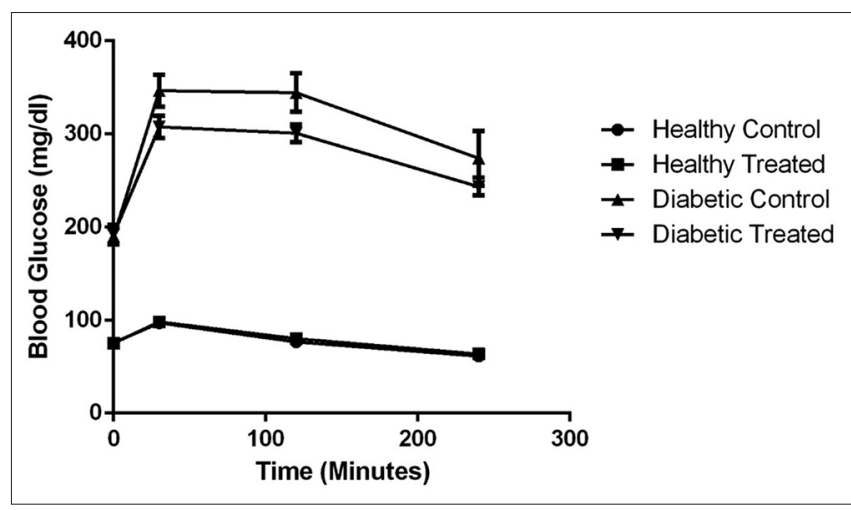

Figure 1: Effect of alfalfa leaves powder with a meal $(8 \mathrm{~g} / \mathrm{subject})$ on plasma glucose levels $(\mathrm{mg} / \mathrm{dl})$ in healthy and diabetic type 2 subject

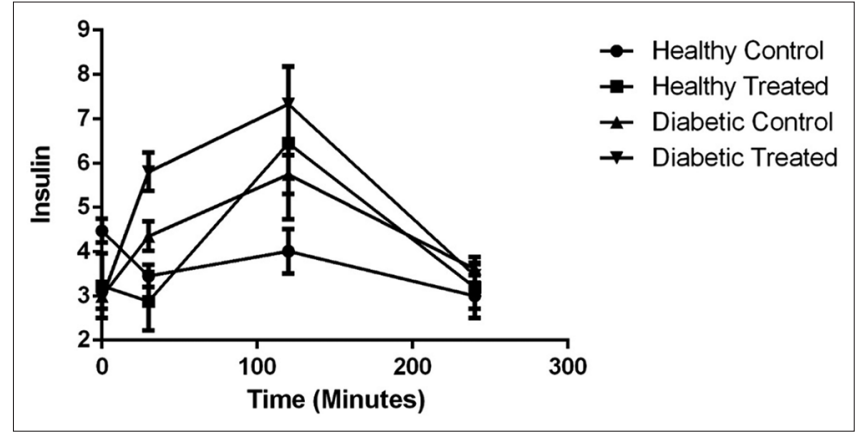

Figure 2: Effect of alfalfa leaves powder with a meal ( $8 \mathrm{~g} / \mathrm{subject})$ on insulin levels $(\mathrm{mcu} / \mathrm{ml})$ in healthy and diabetic type II subject

Table 1: Effect of alfalfa leaves powder with a meal (8 g/subject) on plasma glucose levels (mg/dl) in healthy and diabetic Type 2 subject (Mean \pm SEM)

\begin{tabular}{|c|c|c|c|c|}
\hline Parameters & Baseline minute (mg/dl) & At $30 \mathrm{~min}(\mathrm{mg} / \mathrm{dl})$ & At $120 \mathrm{~min}(\mathrm{mg} / \mathrm{dl})$ & At $240 \mathrm{~min}(\mathrm{mg} / \mathrm{dl})$ \\
\hline Healthy control & $75.66 \pm 1.94$ & $97.00 \pm 5.22$ & $76.66 \pm 2.31$ & $61.33 \pm 2.59$ \\
\hline Healthy treatment & $75.33 \pm 1.64$ & $98.00 \pm 5.59$ & $80.00 \pm 5.97$ & $63.66 \pm 2.13$ \\
\hline$P$ value & 0.8 & 0.8 & 0.8 & 0.8 \\
\hline Diabetic control & $189.9 \pm 8.55$ & $346.60 \pm 17.2$ & $344.40 \pm 20.5$ & $273.90 \pm 29.13$ \\
\hline Diabetic treatment & $192.18 \pm 10.3$ & $307.6 \pm 11.95$ & $300.75+9.37$ & $243.50 \pm 9.49$ \\
\hline$P$ value & 0.8 & 0.06 & 0.03 & 0.5 \\
\hline
\end{tabular}

${ }^{*} P<0.05$ compared with control group

Table 2: Effect of alfalfa leaves powder with a meal $(8 \mathrm{~g} / \mathrm{subject})$ on insulin levels $(\mathrm{mcu} / \mathrm{ml})$ in healthy and diabetic type II subject (Mean \pm SEM)

\begin{tabular}{|c|c|c|c|c|}
\hline Parameters & Baseline minute (mg/dl) & At $30 \mathrm{~min}(\mathrm{mg} / \mathrm{dl})$ & At $120 \mathrm{~min}(\mathrm{mg} / \mathrm{dl})$ & At $240 \mathrm{~min}(\mathrm{mg} / \mathrm{dl})$ \\
\hline Healthy control & $4.47 \pm 0.27$ & $3.45 \pm 0.25$ & $4.01 \pm 0.50$ & $3.00 \pm 0.29$ \\
\hline Healthy treatment & $3.23 \pm 0.73$ & $2.88 \pm 0.66$ & $6.45 \pm 1.72$ & $3.19 \pm 0.69$ \\
\hline$P$ value & 0.1 & 0.4 & 0.05 & 0.2 \\
\hline Diabetic control & $2.99 \pm 0.12$ & $4.35 \pm 0.33$ & $5.74 \pm 0.44$ & $3.61 \pm 0.14$ \\
\hline Diabetic treatment & $2.94 \pm 0.23$ & $5.80 \pm 0.43$ & $7.33 \pm 0.85$ & $3.46 \pm 0.25$ \\
\hline$P$ value & 0.8 & 0.02 & 0.06 & 0.6 \\
\hline
\end{tabular}

${ }^{*} P<0.05$ compared with control group 
in a healthy treated group shows no significant effect compared to the healthy control group $(P=0.8)$. There was significant reduction recorded in blood glucose level of diabetic treated group $(P=0.03)$ when compared to control diabetic group only at $120 \mathrm{~min}$ after treatment, while no significant effect was observed at the rest times after alfalfa treatment in diabetic subjects. This result is in agreement with the reported by Swanston-Flatt et al., 1990 concluding that aqueous extract of alfalfa leave produce significant reduction in blood glucose level of streptozotocin-diabetic mice, although no significant effect was observed in normal (non-diabetic) mice.

Alfalfa leaves are traditionally used in South Africa as an effective treatment for diabetes (Asgary et al., 2008). Hypoglycemic effect of alfalfa leave and its constituents had been proven in the screening study. Since alfalfa stimulates insulin secretion, the pancreatic islet is a possible target of alfalfa (Amraie et al., 2015). Aqueous extract of alfalfa leaves $(1 \mathrm{gm} / \mathrm{ml})$ increased insulin secretion from the BRIN-BD11 pancreatic $\beta$-cell line (Pancreatic islets from rat) at $16.7 \mathrm{mmol}$ glucose concentration. The activity depended on the concentration of extract (Gray and Flatt, 1997). Previous studies showed that adding alfalfa seed in the human diet reduced triglycerides and low-density lipoprotein, improved high-density lipoprotein levels, and decreased blood glucose (Mölgaard et al., 1987).

Further investigation had been done of the effect of alfalfa leaves powder on serum insulin level in healthy and diabetic subjects [Table 2 and Figure 2]. There was a significant elevation in insulin when compared to control.

Administration of alfalfa leave powder with a meal (8 gm/subject) in healthy subjects suppressed the elevation of insulin level significantly at $120 \mathrm{~min}(P=0.05)$.

Furthermore, administration of alfalfa leaves powder with meal $(8 \mathrm{gm} / \mathrm{subject})$ in diabetic subjects suppressed the elevation of insulin level significantly ate $30 \mathrm{~min}$ $P=0.02$ when compared to control diabetic subjects. In a diabetic patient, the best results for the reduction in plasma glucose concentrations with alfalfa were obtained at the lowest concentrations $(2 \mathrm{~h})$ and control over postprandial hyperglycemia has been a strategy for management of diabetes mellitus (Sharma and Kumar, 2016). For the $1^{\text {st }}$ time, the results of this study showed that alfalfa leaves powder significantly reduced plasma glucose concentrations, and elevate serum insulin level in human.

\section{CONCLUSION}

This study concluded that alfalfa leaves powder reduces plasma glucose level in diabetic subjects $2 \mathrm{~h}$ after administration and also proved that alfalfa leaves powder with meal-stimulated insulin secretion from islets of healthy and diabetic subjects.

\section{REFERENCES}

Amraie, E., Farsani, M. K., Sadeghi, L., Khan, T. N., Babadi, V. Y., Adavi, Z. 2015. The effects of aqueous extract of alfalfa on blood glucose and lipids in alloxan-induced diabetic rats. Intervent. Med. Appl. Sci. 7(3): 124-128.

Asgary, S., J. Moshtaghian, M. Hosseini and H. Siadat. 2008. Effects of alfalfa on lipoproteins and fatty streak formation in hypercholesterolemic rabbits. Pak. J. Pharm. Sci. 21(4): 460-464.

Aydin, Y. and E. Önder. 2016. Herbal self-medication use in Type 2 diabetes mellitus. Turk. J. Med. Sci. 46: 1275-1276.

Gray, A. M. and P. R. Flatt. 1997. The traditional plant treatment, Sambucus nigra (elder), exhibits insulin-like and insulinreleasing actions in vitro. J. Nutr. 78: 325-334.

Gray, A. M. and P. R. Flatt. 1998. Antihyperglycemic actions of Eucalyptus globulus (Eucalyptus) areassociated with pancreatic and extra-pancreatic effects in mice. Am. Soc. Nutr. Serv. 128: 2319-2323.

Gregersen, S., P. B. Jeppesen, J. J. Hols and K. Hermansen. 2004. Ant hyperglycemic effects of stevioside in Type 2 diabetic subjects. Metabolism. 53: 73-76.

Mölgaard, J., H. von Scheck and A. G. Olsson. 1987. Alfalfa seeds lower low density lipoprotein cholesterol and apolipoprotein B concentrations in patients with Type II hyperlipoproteinemia. Atherosclerosis. 65(1-2): 173-179.

Nathan, D. M. 2014. The diabetes control and complications trial/ epidemiology of diabetes interventions and complications study at 30 years. Overv. Group J. Diabetes Care. 37(1): 44-49.

Sharma, H. and S. Kumar. 2016. Management of metabolic syndrome by some herbs ethnic to Western Himalayan region of Himachal Pradesh. J. Pharmacogn. Phytochem. 5(3): 192-195.

Swanston-Flatt, S. K., C. Day, C. J. Bailey and P. R. Flatt. (1990) Traditional plant treatments for diabetes. Studies in normal and streptozotocin diabetic mice. Diabetologia. 33(8): 462-464. 